\title{
DISTRIBUTION OF HEPATITIS C VIRUS GENOTYPES AND SUBTYPES IN A GROUP OF PATIENTS WITH CHRONIC HEPATITIS C FROM CANTON SARAJEVO, 2012-2018
}

\author{
Irma Salimović-Bešić ${ }^{1,2}$, Adna Kahriman ${ }^{3}$, Suzana Arapčić ${ }^{1}$, Amela Dedeić-Ljubovićc ${ }^{1,2,4}$
}

(C) 2019 by Acta Medica Saliniana

ISSN 0350-364X

DOI: $10.5457 / 524$

Irma Salimović-Bešić

Adna Kahriman

Suzana Arapčić

Amela Dedeić-Ljubović

\section{Afiliations:}

${ }^{1}$ Clinical Center of the University of Sarajevo, Unit for Clinical Microbiology, ${ }^{2}$ University of Sarajevo, Faculty of Health Sciences,

3Pharma Maac d.o.o,

${ }^{4}$ University Sarajevo School of Science and Technology, Sarajevo Medical School, 71 ooo Sarajevo, Bosnia and Herzegovina

\section{Corresponding author:}

Irma Salimović-Bešić

E-mail: irma.salimovic_besic@yahoo.com

\section{ABSTRACT}

Background: Hepatitis C virus (HCV) genotypes and subtypes exhibit significant geographic variations.

Aim: To analyse the distribution of genotypes/subtypes of HCV in a group of patients with chronic hepatitis C from Canton Sarajevo during 2012-2018.

Material and methods: The study enrolled 247 human plasma samples of HCV-RNA positive patients with available results of $\mathrm{HCV}$ genotyping test.

Results: During 2012-2018, the domination of subtypes 1a (34.01\%), 1b (28.34\%) and genotype $3(23.89 \%)$ was registered. In 2012 and 2013 , HCV subtype 1a was the most common (27/63;42.86\% and $17 / 40 ; 42.50 \%$, respectively). In 2014, the leading $\mathrm{HCV}$ genotype/subtype were 3 and $\mathrm{lb}(17 / 57 ; 29.82 \%)$. In 2015, the dominance of HCV genotype $3(14 / 39 ; 35.90 \%)$ continued, while in 2016 , the same number of HCV subtypes 1a and $\mathrm{lb}(11 / 30 ; 36.67 \%)$ was recorded. Although in a small number of tested, during 2017 , HCV subtype $\mathrm{ib}$ was the most prevalent (7/14; 50.00\%), and in 2018, it was replaced by a HCV subtype a $(3 / 4 ; 75.00 \%)$. Distribution of $\mathrm{HCV}$ genotypes/subtypes by age group of patients varied significantly $(\mathrm{p}=0.000)$. The largest number of patients (71/247; 28.74\%) belonged to the age category $30-39$ years and $\mathrm{HCV}$ genotypes/subtypes 1, 3, 4, 1a and $1 \mathrm{~b}$ were identified. Except in 2017, male gender significantly dominated $(\mathrm{p}=0.000)$. In males, $\mathrm{HCV}$ subtype $1 \mathrm{a}(68 / 170 ; 40.00 \%)$ was the most common, while in women it was HCV subtype $1 \mathrm{~b}(44 / 77 ; 57.14 \%)$.

Conclusion: This six-year retrospective study showed the time variations of the circulating HCV genotypes/subtypes among patients with chronic hepatitis $\mathrm{C}$ in Canton Sarajevo. Genotyping of the HCV has an important implications for diagnosis and treatment of the patients.

Key words: hepatitis C, genotype, prevalence

\section{INTRODUCTION}

Based on the WHO estimation from 2015, 71 million persons were living with chronic hepatitis $\mathrm{C}$ virus (HCV) infection worldwide and 399 ooo died from cirrhosis or hepatocellular carcinoma caused by HCV infection. In the same year, 1.75 million new $\mathrm{HCV}$ infections occurred, mostly among people who inject drug (PWID) and with unsafe health care [1]. According to the phylogenetic and sequence analysis of whole viral genomes worldwide, HCV infection may be caused by one of seven recognized genotypes (1-7) [2]. Within genotypes, $\mathrm{HCV}$ is then classified into 67 confirmed and 20 provisional subtypes. The differences between HCV genotypes vary in $30-35 \%$ of the nucleotides, while the strains within the same subtype differ at $<15 \%$ of nucleotide sites [3].

Distribution of $\mathrm{HCV}$ genotypes and subtypes exhibits significant geographic variations. In meta-analysis involving 1.217 studies, representing 117 countries and $90 \%$ of the global population, HCV genotype 1 was the most prevalent worldwide (83.4 million cases; $46.2 \%$ of all HCV cases), with approximately onethird recorded in East Asia. Genotype 3 was the next most prevalent globally ( 54.3 million, 30.1\%); genotypes 2, 4 , and 6 were responsible for a total $22.8 \%$ of all cases; genotype 5 comprises the remaining $<1 \%$. Genotypes 1 and 3 dominated in most countries regardless of their economic 
status, while genotypes 4 and 5 were mostly present in low-income countries [4].

With a more detailed insight into the prevalence of $\mathrm{HCV}$ genotypes, it was seen that the south and eastern European countries follow the dominance of subtypes 1 b, 3 and 1a. Genotype 1 is distributed worldwide and is responsible for most cases in America, Europe, Australia and Japan; subtype $1 \mathrm{~b}$ is most common in Europe and Asia, while subtype ra is widespread in northern Europe and the United States. Genotype 2 is more common in industrialized countries, as well as in South America and Asia, especially in Japan and China, where subtype $2 \mathrm{a}$ is usually isolated; subtype $2 \mathrm{~b}$ is widespread in Northern Europe and the United States; genotype $2 \mathrm{c}$ is the most common subtype in Western and Southern Europe, Pakistan and India. Genotype 3, and especially subtype za, predominates in Europe, the US, Australia and South Asia [5-7].

Genotypes 4 and 5 are mainly identified in Africa and the Middle East: the subtype 4a is prevalent in Egypt, while the subtype $4 \mathrm{C}$ is widespread in Central Africa; genotype 5 is largely isolated in South Africa. Genotype 6 and its many subtypes are found predominantly in Southeast Asia, and in some countries such as Thailand, Vietnam and Myanmar, genotype 6 is responsible for most new HCV cases. It is believed that genotypes 4, 5 and 6 are limited to North Africa, Central Africa and Southeast Asia, but rising migration and globalization processes cause the spread of these genotypes beyond those areas, in the nearby regions of Asia, and far to Western countries such as the United States, Canada and Northern Europe. Genotype 7 has little clinical relevance and has recently been found in patients from Central Africa and Thailand [8-14]. In developing countries, an age-related distribution of cases and a virus transmission linked to unsafe medical procedures and blood transfusions have been observed; however, recent data indicated an increasing role in the spread of infection played by injection drug use [15].

In Bosnia and Herzegovina $(\mathrm{B} \& \mathrm{H})$, a limited range of data based on molecular epidemiology of HCV is available so far, showing the major prevalence of subtypes $1 \mathrm{a}$ and/or $1 \mathrm{~b}$ and genotype 3, respectively, depending on age, gender and risk category of study population [16-17]. Because of its high genetic diversity, HCV has been considered a major challenge for the development of $\mathrm{HCV}$ vaccines and pan-genotypic therapies [18]. Currently, the duration of treatment, cure rates, and the need for adjuvant interferon and ribavirin with the new direct-acting antiviral (DAA) therapies remain dependent in part on HCV genotype and subtype.

An initial therapy that has been used in B\&H consisted of pegylated interferon plus ribavirin combination therapy administered for 48 weeks in patients with genotype 1, while treatment with lower doses of ribavirin has been equally effective in patients with genotype 2 and 3 for 24 weeks. Because of the lack of data on the nature of the disease caused by the HCV genotypes 4, 5 and 6 , a rigorous regimen of treatment as for genotype 1 was in place.

Treatment of patients with chronic hepatitis $C$ using interferon free new DAA therapy (e.g. sofosbuvir/ ledipasvir) has been available in $\mathrm{B} \& \mathrm{H}$ since 2016. The therapy is administered as a simple one-tablet regimen, once a day for 8-12 weeks for most patients, alone or with ribavirin, and has shown exceptional efficiency (94-100\%) for HCV genotypes 1, 4, 5 and 6 [19-21].

However, the development of national treatment strategies using DAA therapies requires better knowledge of the epidemiology of HCV and of the distribution of its genotypes. Therefore, the aim of this study was to analyse the distribution of genotypes/ subtypes of HCV in a group of patients with chronic hepatitis C from Canton Sarajevo during 2012-2018, as a contribution to the planning of the preventive and therapeutic actions, allowing determination of the need for treatment of infected persons.

\section{SUBJECTS AND METHODS}

The research was carried out at the Clinical Center of the University of Sarajevo, Unit for Clinical Microbiology. Study enrolled 247 HCV RNA-positive patients suffering from chronic hepatitis C from Canton Sarajevo (one of the ten cantons of the entity Federation of B\&H within the country B\&H) during the period of 2012-2018. Participants were divided into eight age groups: I (o-9 years), II (10-19 years), III (2029 years), IV (30-39 years), V (40-49 years), VI (5059 years old), VII (6o-69 years) and VIII (>70 years) and considered by gender (male, female). For the patients' identity protection, all samples were tested anonymously and coded. Blood samples were collected by standard vacutainer system method and plasma fraction was used for molecular diagnostics.

HCV genotyping was performed by automated system m20oo (Abbott Molecular Inc., IL, SAD) at Clinical Center of the University of Sarajevo, Unit for Clinical Microbiology. The system consisted from m2ooosp instrument for extraction and purification of RNA from human plasma samples and preparation of multiplex real-time reverse-transcription polymerase chain reactions (rtRT-PCR), and instrument mzooort for running of rtRT-PCR.

The Abbott m2ooosp provides automated sample preparation using a magnetic microparticle-based protocol (Abbott mSample Preparation System, Promega Corporation, Madison, WI, SAD) to process $0,5 \mathrm{~mL}$ of samples. During the sample preparation protocol, HCV virions were disrupted by guanidine isothiocyanate, RNA was captured on the magnetic microparticles, inhibitors were removed by washing steps, and RNA was eluted off the microparticles. The 
bound nucleic acids were eluted and transferred to a 96 deep-well plate for amplification. The Internal Control (IC) was introduced into each specimen at the beginning of the sample preparation process to demonstrate that the process was completed correctly for each specimen and control.

The Abbott mzooosp instrument automated the assembly of three amplification master mixes (A, B, and $C$ ) by combining the respective Abbott RealTime HCV Genotype II Oligonucleotide Reagent (A, B, or C) with thermostable rTth DNA polymerase enzyme and Activation Reagent. The instrument dispensed the resulting master mixes into the 96-well optical reaction plate along with aliquots of the nucleic acid samples prepared by the Abbott mzooosp. Each processed sample was added to one well containing Master Mix $\mathrm{A}$, one well containing Master Mix B, and one well containing Master Mix C.

The Abbott RealTime HCV Genotype II assay used four sets of PCR primers. One set of primers targeted a sequence within the 5 ' untranslated region (UTR) of the HCV genome. This primer set was designed to amplify all HCV isolates. The second primer set was designed to amplify the non-structural $5 \mathrm{~b}\left(\mathrm{NS}_{5} \mathrm{~b}\right)$ region of genotype a. The third HCV primer set amplified the $\mathrm{NS}_{5} \mathrm{~b}$ region of genotype $\mathrm{ib}$. The IC primer set targeted a portion of the hydroxypyruvate reductase gene of the pumpkin plant, Cucurbita pepo, and was delivered in an Armored $\mathrm{RNA}^{\circ}$ particle that was diluted in negative human plasma.

The assay required three separate reactions to detect genotypes 1, 1a, 1b and 2-5: Reaction A detected all $\mathrm{HCV}$ isolates, type 3 isolates, and subtype ra isolates. Reaction $\mathrm{B}$ was designed to detect type 1 isolates, type 2 isolates, and subtype $1 b$ isolates, and reaction $C$ was used to detect type 4 and type 5 isolates.

\section{Statistics}

Descriptive statistics were expressed by frequency, arithmetic mean, standard deviation (SD), minimum and maximum values, and percentages. As statistical procedures, Kolmogorov-Smirnov test, Kruskal-Wallis test and Chi-square test were applied. Statistical analysis was performed using Excel (Microsoft Office) and IBM SPSS Statistics 23.0 (IBM, New York, USA). A $\mathrm{p}$-value of $<0.05$ was considered statistically significant.

\section{RESULTS}

The results were analysed in the total population tested for HCV genotyping in the period of 2012-2018, and annually. The most prevalent HCV genotype/subtype in the population during $2012-2018$ was 1a $(84 / 247$; $34.01 \%)$, followed by subtype $1 \mathrm{~b}(70 / 247 ; 28.34 \%)$, and genotype $3(59 / 247 ; 23.89 \%)$ (Table 1$)$.

Table 1. Distribution of HCV genotypes/subtypes by age groups, 2012-2018.n- number of participants

\begin{tabular}{|c|c|c|c|c|c|c|c|c|c|c|c|c|c|c|c|c|c|c|}
\hline \multirow{3}{*}{$\begin{array}{c}\text { HCV } \\
\text { genotype/ } \\
\text { subtype }\end{array}$} & \multicolumn{16}{|c|}{$\begin{array}{l}\text { Age group } \\
\text { (years) }\end{array}$} & \multirow{2}{*}{\multicolumn{2}{|c|}{ Total }} \\
\hline & \multicolumn{2}{|c|}{$\begin{array}{c}I \\
(0-9)\end{array}$} & \multicolumn{2}{|c|}{$\begin{array}{c}\text { II } \\
(10-19)\end{array}$} & \multicolumn{2}{|c|}{$\begin{array}{c}\text { III } \\
(20-29)\end{array}$} & \multicolumn{2}{|c|}{$\begin{array}{c}\text { IV } \\
(30-39)\end{array}$} & \multicolumn{2}{|c|}{$\begin{array}{c}V \\
(40-49)\end{array}$} & \multicolumn{2}{|c|}{$\begin{array}{c}\text { VI } \\
(50-59)\end{array}$} & \multicolumn{2}{|c|}{$\begin{array}{c}\text { VII } \\
(60-69)\end{array}$} & \multicolumn{2}{|c|}{$\begin{array}{l}\text { VIII } \\
(>70)\end{array}$} & & \\
\hline & $\mathrm{n}$ & $\%$ & $\mathrm{n}$ & $\%$ & $\mathrm{n}$ & $\%$ & $\mathrm{n}$ & $\%$ & $\mathbf{n}$ & $\%$ & $\mathrm{n}$ & $\%$ & $\mathrm{n}$ & $\%$ & $\mathrm{n}$ & $\%$ & $\mathrm{n}$ & $\%$ \\
\hline 1 & I & I & I & I & 3 & 12.50 & 5 & 7.04 & 2 & 3.33 & 3 & 5.45 & 2 & 6.90 & l & I & 15 & 6.07 \\
\hline 2 & I & I & I & / & / & I & I & I & 2 & 3.33 & 1 & 1.82 & I & I & I & I & 3 & 1.21 \\
\hline 3 & I & 1 & 1 & 25.00 & 12 & 50.00 & 21 & 29.58 & 18 & 30.00 & 5 & 9.09 & 1 & 3.45 & 1 & 33.33 & 59 & 23.89 \\
\hline 4 & 1 & 100.00 & I & I & 3 & 12.50 & 6 & 8.45 & 2 & 3.33 & 2 & 3.64 & 2 & 6.90 & l & / & 16 & 6.48 \\
\hline 1a & 1 & I & 1 & 25.00 & 5 & 20.83 & 36 & 50.70 & 29 & 48.33 & 12 & 21.82 & 1 & 3.45 & 1 & I & 84 & 34.01 \\
\hline $1 \mathrm{~b}$ & I & I & 2 & 50.00 & 1 & 4.17 & 3 & 4.23 & 7 & 11.67 & 32 & 58.18 & 23 & 79.31 & 2 & 66.67 & 70 & 28.34 \\
\hline Total & 1 & 0.40 & 4 & 1.62 & 24 & 9.72 & 71 & 28.74 & 60 & 24.29 & 55 & 22.27 & 29 & 11.74 & 3 & 1.22 & 247 & 100.00 \\
\hline
\end{tabular}

The largest number of HCV genotyping tests performed was recorded in $2012(63 / 247 ; 25.51 \%)$, followed by $2014(57 / 247 ; 23.08 \%)$ and $2013(40 / 247 ; 16.19 \%)$. In the period of 2015-2018, there was a continuous decline in the number of tested individuals (Figure 1).

In 2012 and 2013, HCV subtype 1a was the most common (27/63; 42.86\% and $17 / 40 ; 42.50 \%$, respectively). In 2014, the leading HCV genotype/subtype were 3 and lb $(17 / 57 ; 29.82 \%)$. In 2015, the dominance of $\mathrm{HCV}$ genotype 3 (14/39; 35.90\%) continued, while in 2016, the same number of HCV subtypes $1 \mathrm{a}$ and $1 \mathrm{~b}(11 / 30$; $36.67 \%)$ was recorded. Although in a small number of tested, during 2017, HCV subtype $1 \mathrm{~b}$ was the most prevalent $(7 / 14 ; 50.00 \%)$, and in 2018 , it was replaced by a $\mathrm{HCV}$ subtype a $(3 / 4 ; 75.00 \%)$ (Figure 1$)$.

The genotype distribution varied across age categories. An average age of the participants was 44.11 years (STDEV \pm 12.44$)$. The youngest among them was 9, and 
the oldest was 79 years old. The $50 \%$ of patients had $\leq 43$ years. According to the age group, the majority of patients $(71 / 247 ; 28.74 \%)$ belonged to the group IV (3039 years), followed by the group $\mathrm{V}$ (40-49 years) with $60 / 247(24.29 \%)$ patients, while the smallest number of tested $(1 / 247 ; 0.40 \%)$ was recorded in the group I (o-9 years) (Table 1 ). In the youngest age group (I, o-9 years), only one patient was present with HCV genotype 4 identified. The widest spectrum of genotypes/subtypes $(1,2,3,4$, 1a and $1 \mathrm{~b})$ was identified in the age groups $\mathrm{V}$ (40-49 years) and VI (50-59 years), while in the group of oldest patients VIII (>70 years), HCV genotype 3 and subtype $1 b$ were recorded (Table 1 ).

The highest frequency among age groups belonged to HCV subtype 1a $(36 / 71 ; 50.70 \%)$ found within the age group IV (30-39 years) and then by HCV subtype 1 b $(32 / 55 ; 58.18 \%)$, which was the most frequently identified in age group VI (50-59 years). The dominance of individual genotypes/subtypes among age groups of the patients is given in Table 1.
The difference in the prevalence of HCV genotypes/ subtypes according to the age of participants was statistically significant $(\mathrm{p}=0.000)$. Actually, the age variable for HCV genotype/subtype $1(\mathrm{p}=0.543)$, 1a $(\mathrm{p}=0.487), 2(\mathrm{p}=0.960), 3(\mathrm{p}=0.384)$, and $4(\mathrm{p}=0.884)$ followed the normal distribution $(\mathrm{p} \geq 0.05 ; \mathrm{a}$ nonparametric Kolmogorov-Smirnov test was used) while for subtype $1 b$, the normal distribution of the values was not followed $(\mathrm{p}<0.05 ; \mathrm{p}=0.038)$ and $\mathrm{a}$ nonparametric test for $\mathrm{k}$ independent samples was applied (Kruskal-Wallis test).

In the period 2012-2018, the testing of the male population significantly dominated (170/247; 68.83\%; $\mathrm{p}=0.000$ ) and the most common HCV genotype/ subtype was 1a $(68 / 170 ; 40.00 \%)$, followed by the genotype $3(50 / 170 ; 29.41 \%)$, while in the female population the subtype $1 \mathrm{~b}$ was the most common (44/77; $57.14 \%)$, followed by subtype 1a $(16 / 77 ; 20.78 \%)$ (Table 2).

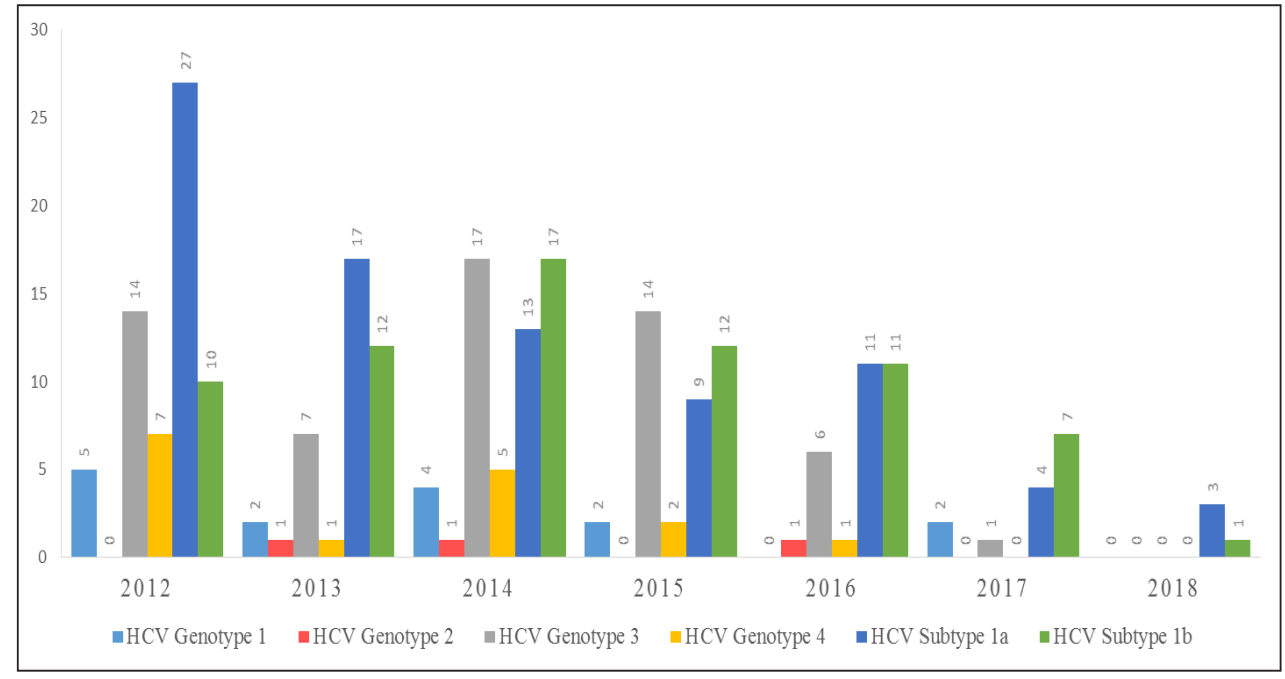

Figure 1. Annual distribution of HCV genotypes/subtypes, 2012-2018.

Table 2. Distribution of HCV genotypes/subtypes by gender, 2012-2018.

\begin{tabular}{ccccccc}
$\begin{array}{c}\text { HCV } \\
\text { genotype/subtype }\end{array}$ & \multicolumn{2}{c}{ Male } & \multicolumn{2}{c}{ Female } & \multicolumn{2}{c}{ Total } \\
\hline $\mathbf{1}$ & $\mathbf{n}$ & $\mathbf{\%}$ & $\mathbf{n}$ & $\mathbf{\%}$ & $\mathbf{n}$ & $\mathbf{\%}$ \\
$\mathbf{2}$ & 10 & 5.88 & 5 & 6.49 & 15 & 6.07 \\
$\mathbf{3}$ & 2 & 1.18 & 1 & 1.30 & 3 & 1.21 \\
$\mathbf{4}$ & 50 & 29.41 & 9 & 11.69 & 59 & 23.89 \\
$\mathbf{1 a}$ & 14 & 8.24 & 2 & 2.60 & 16 & 6.48 \\
$\mathbf{1 b}$ & 68 & 40.00 & 16 & 20.78 & 84 & 34.01 \\
Total & $\mathbf{2 6}$ & 15.29 & 44 & 57.14 & 70 & 28.34 \\
& $\mathbf{1 7 0}$ & 68.83 & $\mathbf{7 7}$ & 31.17 & $\mathbf{2 4 7}$ & $\mathbf{1 0 0 . 0 0}$
\end{tabular}




\section{DISCUSSION}

Persistent HCV infection is associated with the development of liver cirrhosis, hepatocellular cancer, liver failure, and death [22].Since epidemiological data are the basis for the development of preventive strategies necessary for eradication of HCV infection, the aim of this study was to update and review the molecular epidemiology of $\mathrm{HCV}$ in a part of $\mathrm{B} \& \mathrm{H}$ (capital region) as a contribution to the development of national-specific screening programs and the international HCV surveillance program. Several studies in $\mathrm{B} \& \mathrm{H}$ were conducted on the prevalence of HCV genotypes/subtypes. In the study published in 2007 [16], with the group of treated chronic hepatitis $C$ patients, subtype 1a was the most prevalent (46\%), followed by subtype $1 \mathrm{~b}$ and genotype 3 in the same percentage $(22 \%)$.

In the later study from 2009 [17], which enrolled the samples collected during 2006-2008, the prevalence of HCV genotypes in patients with chronic hepatitis $\mathrm{C}$ and first time blood donors from northeastern $\mathrm{B} \& \mathrm{H}$ region, according to gender and age group, was assessed. In both analysed populations, subtype $1 \mathrm{~b}$ was the most frequent, followed by genotype 3 and subtype 1a. Subtype 1a was more prevalent in the first time blood donors but with limited statistical significance. The largest age group among both populations assessed was 30-50 years, and male gender dominated among all respondents of the study.

The most prevalent $\mathrm{HCV}$ infection revealed in the patients with chronic hepatitis C during 2012-2018 in Canton Sarajevo was caused by subtype 1a (34.01\%), followed by subtype 1 b (28.34\%), and genotype 3 $(23.89 \%)$. Our results showed a continuing trend of dominance of subtypes $1 \mathrm{a}$ and $1 \mathrm{~b}$ over the time in this part of $\mathrm{B} \& \mathrm{H}$, reffering the higher similarity to study from 2007 [16]. Comparing with the available data from the neighbouring countries, the results of eight-year (2008-2015) retrospective study on the distribution of $\mathrm{HCV}$ genotypes and subtypes in $3.655 \mathrm{HCV}$-infected individuals from Croatia showed that the majority of infections were also attributed to genotypes 1 and 3, without major changes in the molecular epidemiology in Croatia in the past 20 years [23].

In Europe, subtype 1a and genotype 3 (including subtype za) are mostly found in PWID, whereas subtype $1 \mathrm{~b}$ and genotypes 2 are usually associated with blood transfusion and unsafe medical procedures [24]. The most common genotype found in Central European countries is genotype $1(70.0 \%)$, followed by genotype 3 (21.0\%), 4 (4.9\%) and 2 (3.2\%). Only a small percentage of mixed genotypes and genotype 6 has been found, whereas genotype 5 cases were not reported according to the study from 2015 [25]. Actually, in Romania, Hungary and Slovakia, genotype 1 is almost the only genotype found (98.0; 94,1 and 89,9\%, respectively). A significant percentage of genotype 3 was described in Macedonia (44,6\%), Slovenia (37.8\%) and Croatia (35.6\%), while a considerable prevalence of genotype 2 was revealed only in Albania (20.0\%) and of genotype 4 in Montenegro (19.6\%) and Albania (16.0\%) [25].

It is necessary to emphasize that the range of detected genotypes largely depends on the method used to determine the HCV genotype. In our study, we were limited to the detection of HCV genotypes/subtypes $1,1 a, 1 b, 2-5$ by the method used, not excluding the possibility of the presence of other genotypes/subtypes circulated in the region. The gold standard of HCV genotyping is the sequencing of $\mathrm{NS}_{5} \mathrm{~B}$ region, capable to accurately assign the genotype, and the resulting sequence can be used for phylogenetic analysis to epidemiological purposes [26-29]. HCV prevalence in the majority of developed countries is classified as low, but marked differences in the epidemiological picture exist among countries, principally related to temporal and transmission factors and resulted in diverse agespecific distribution of HCV cases [30].

In our study, the prevalence of HCV genotypes/subtypes according to the age group of patients was significantly different. Thus, the majority of patients $(28.74 \%)$ belonged to the group of 30-39 years, followed by the group of $40-49$ years with $24.29 \%$ of patients. Looking for the similar results among other countries, we found that also in Australia and in the United States, the peak prevalence was recorded in people aged 30-39 years, probably related to an increase of parenteral drug use throughout the 1980s and 1990s [31-32]. Among developed countries with a low prevalence of HCV infection, Japan shows the most of HCV cases recorded in people aged 40-69 years, while HCV prevalence in younger people was very low, suggesting the occurrence of infection in the distant past, linked to the possible improper sterilization procedures and unsafe medical practice [33-35].

In the period 2012-2018, testing of the male population significantly dominated $(68.83 \%)$ with the most common HCV subtype 1a and genotype 3 detected, while in the female population, subtype $1 \mathrm{~b}$ was the most common, followed by the subtype ra. The male population was also more prevalent in the study from 2009 [17], but the distribution was somewhat different, with the dominance of subtypes $1 \mathrm{~b}$ and 3 in both, males and females. Among the study group, during the 20152018, a continuous decline in the number of tested people was observed, indicating the possible benefits of the use of effective therapy on the population. Currently, the development of highly effective therapy against HCV infection could substantially contribute to better control and the treatment of the patients.

Although HCV genetic diversity on a national and regional level indicates the need for continuous surveillance of HCV molecular epidemiology, according to the updated WHO Guidelines recommendation, the use of pan-genotypic regimens will reduce the need for genotyping before initiation of the treatment [36]. The potential limitation of the study was an incomplete total number of patients from Canton Sarajevo, representing the group of those tested at the Clinical 
Center of the University of Sarajevo during the study period.

In conclusion, consideration of the trend in the prevalence of $\mathrm{HCV}$ genotypes in a particular region is a challenge for the improved development of vaccines and pan-genotypic treatments. Our results confirmed the domination of genotypes $1 \mathrm{a}, \mathrm{1b}$ and 3 during 20122018 in a group of patient with chronic hepatitis $C$ in Canton Sarajevo, which is accordance to the similar results from $2007(\mathrm{~B} \& \mathrm{H})$ and countries from the region. Distribution of genotypes indicates the possible trnsmission routes by PWID, blood transfusion and unsafe medical procedures.

\section{SAŽETAK}

Uvod: Genotipovi i podtipovi hepatitis C virusa (HCV) pokazuju značajne geografske varijacije.

Cilj: Analizirati distribuciju genotipova i podtipova $\mathrm{HCV}$-a kod grupe bolesnika sa hroničnim hepatitisom $\mathrm{C}$ iz Kantona Sarajevo, u periodu 2012-2018.

Materijal i metode: U istraživanje je uključeno 247 uzoraka humane plazme HCV-RNK pozitivnih ispitanika sa raspoloživim rezultatima testa genotipizacije HCV-a.

Rezultati: Tokom 2012.-2018. godine, zabilježena je dominacija HCV podtipova 1a (34,01\%), 1b $(28,34 \%)$ i genotipa 3 (23,89\%). U 2012. i 2013. godini, HCV podtip 1a bio je najčešći $(27 / 63 ; 42,86 \%$ i $17 / 40 ; 42,50 \%)$. U 2014. godini, preovladavali su HCV genotip 3 i podtip $1 \mathrm{~b}(17 / 57 ; 29,82 \%)$. U 2015. godini nastavljena je dominacija HCV genotipa 3 (14/39; 35,90\%), dok je u 2016. godini zabilježen isti broj HCV podtipova 1a i 1 b (11/30; 36,67\%). Iako u malom broju testiranih, tokom 2017. godine, $\mathrm{HCV}$ podtip $\mathrm{ib}$ je bio najrašireniji $(7 / 14 ; 50,00 \%)$, a 2018 . godine je bio zamijenjen $\mathrm{HCV}$ podtipom 1a $(3 / 4 ; 75,00 \%)$. Distribucija $\mathrm{HCV}$ genotipova/podtipova prema starosnoj kategoriji bolesnika značajno je varirala $(\mathrm{p}=0,000)$. Najveći broj ispitanika $(71 / 247 ; 28,74 \%)$ je pripadao starosnoj kategoriji od 30-39 godina, u kojoj su identifikovani HCV genotipovi/podtipovi 1, 3, 4, la i ıb. Osim u 2017. godini, značajno je dominirao muški spol $(\mathrm{p}=\mathrm{o}, \mathrm{ooo})$ među testiranim. Kod muškaraca je najčešći bio HCV podtip ra $(68 / 170 ; 40,00 \%)$, dok je kod žena bio HCV podtip 1 b (44/77; 57,14\%).

Zaključak: Ova šestogodišnja retrospektivna studija pokazala je vremenske varijacije cirkulirajućih HCV genotipova/podtipova među ispitanicima sa hroničnim hepatitisom C u Kantonu Sarajevo. Genotipizacija HCV-a ima važne implikacije za dijagnozu i liječenje pacijenata.

Ključne riječi: hepatitis $C$, genotip, prevalenca

\section{REFERENCES}

1. Global hepatitis report, 2017. Geneva: World Health Organization; 2017

2. Simmonds P, Alberti A, Alter HJ, Bonino F, Bradley DW, Brechot C, Brouwer JT, Chan SW, Chayama K, Chen DS. A proposed system for the nomenclature of hepatitis $C$ viral genotypes. Hepatology 1994; 19: 1321-1344.

3. Smith DB, Bukh J, Kuiken C, Muerhoff AS, Rice CM, Stapleton JT, Simmonds P. Expanded classification of hepatitis $C$ virus into 7 genotypes and 67 subtypes: updated criteria and genotype assignment web resource. Hepatology 2014; 59: 318-327.

4. Messina JP, Humphreys I, Flaxman A, Brown A, Cooke GS, Pybus OG, Barnes E. Global distribution and prevalence of hepatitis $C$ virus genotypes. Hepatology 2015; 61: 77-87.

5. Chlabicz S, Flisiak R, Kowalczuk O, Grzeszczuk A, Pytel-Krolczuk B, Prokopowicz D, Chyczewski L. Changing HCV genotypes distribution in Poland--relation to source and time of infection. J Clin Virol 2008; 42: 156-159.

6. Tallo T, Norder H, Tefanova V, Krispin T, Schmidt J, Ilmoja M, Orgulas K, Pruunsild K, Priimägi L, Magnius LO. Genetic characterization of hepatitis $C$ virus strains in Estonia: fluctuations in the predominating subtype with time. J Med Virol 2007; 79: 374-382.

7. Katsoulidou A, Sypsa V, Tassopoulos NC, Boletis J, Karafoulidou A, Ketikoglou I, Tsantoulas D, Vafiadi I, Hatzis G, Skoutelis A, Akriviadis E, Vasiliadis T, Kitis G, Magiorkinis G, Hatzakis A. Molecular epidemiology of hepatitis $C$ virus $(\mathrm{HCV})$ in Greece: temporal trends in $\mathrm{HCV}$ genotype-specific incidence and molecular characterization of genotype 4 isolates. J Viral Hepat 2006; 13: 19-27.

8. Barritt AS, Fried MW. Maximizing opportunities and avoiding mistakes in triple therapy for hepatitis C virus. Gastroenterology 2012; 142: 1314-23.e1

9. FDA Drug Safety Communication. Serious skin reactions after combination treatment with the Hepatitis C drugs Incivek (telaprevir), peginterferon alfa, and ribavirin. 19 December 2012. Available from: URL: http://www.fda.gov/ Drugs/DrugSafety/ucm332731.htm

10. Schaefer EA, Chung RT. Anti-hepatitis $C$ virus drugs in development. Gastroenterology 2012; 142: 1340-50.e1

11. Khaliq S, Jahan S, Pervaiz A. Sequence variability of HCV Core region: important predictors of $\mathrm{HCV}$ induced pathogenesis and viral production. Infect Genet Evol 2011; 11: 543-56.

12. Vieyres G, Thomas X, Descamps V, Duverlie G, Patel AH, Dubuisson J. Characterization of the envelope glycoproteins associated with infectious hepatitis C virus. J Virol 2010; 84: 10159-10168.

13. Thimme R, Binder M, Bartenschlager R. Failure of innate and adaptive immune responses in controlling hepatitis $\mathrm{C}$ virus infection. FEMS Microbiol Rev 2012; 36:663-83.

14. Gale M, Foy EM. Evasion of intracellular host defence by hepatitis $C$ virus. Nature 2005; 436: 939-945.

15. Ansaldi F, Orsi A, Sticchi L, Bruzzone B, Icardi G. Hepatitis $C$ virus in the new era: perspectives in epidemiology, prevention, diagnostics and 
predictors of response to therapy. World J Gastroenterol 2014; 20: 9633-9652.

16. Vukobrat-Bijedić Z, Husić-Selimović A, Radović S, Gornjaković S, Gogov B, Zubčević N, Bilalović N, Koluder N. Evaluacija genotipa hepatitis $\mathrm{C}$ virusa i njegov uticaj na terapijski odgovor pegiliranim interferonom alfa $2 \mathrm{a}(40) \mathrm{kD} u$ kombinaciji sa Ribavirinom. Med Arh 2007; 61: 221-224.

17. Ahmetagić S, N Salkić N, Cickusić E, Zerem E, Mott-Divković S, Tihić N, Smriko-Nuhanović A. Hepatitis $C$ virus genotypes in chronic hepatitis $C$ patients and in first time blood donors in northeastern Bosnia and Herzegovina. Bosn J Basic Med Sci 2009; 9: 278-282.

18. Timm J, Roggendorf M. Sequence diversity of hepatitis $C$ virus: implications for immune control and therapy. World J Gastroenterol 2007; 13: 48o8-4817.

19. Terrault NA, Zeuzem S, Di Bisceglie AM, Lim JK, Pockros PJ, Frazier LM, Kuo A, Lok AS, Shiffman ML, Ben Ari Z, Akushevich L, Vainorius M, Sulkowski MS, Fried MW, Nelson DR; HCV-TARGET Study Group. Effectiveness of ledipasvir-sofosbuvir combination in patients with hepatitis $C$ virus infection and factors associated with sustained virologic response. Gastroenterology 2016; 151: 1131-1140.

20. Afdhal N, Zeuzem S, Kwo P, Chojkier M, Gitlin N, Puoti M, Romero-Gomez M, Zarski JP, Agarwal K, Buggisch P, Foster GR, Bräu N, Buti M, Jacobson IM, Subramanian GM, Ding X, Mo H, Yang JC, Pang PS, Symonds WT, McHutchison JG, Muir AJ, Mangia A, Marcellin P; ION-1 Investigators. Ledipasvir and sofosbuvir for untreated $\mathrm{HCV}$ genotype 1 infection. N Engl J Med 2014; 370: 1889-1898.

21. Kowdley KV, Gordon SC, Reddy KR, Rossaro L, Bernstein DE, Lawitz E, Shiffman ML, Schiff E, Ghalib R, Ryan M, Rustgi V, Chojkier M, Herring R, Di Bisceglie AM, Pockros PJ, Subramanian GM, An D, Svarovskaia E, Hyland RH, Pang PS, Symonds WT, McHutchison JG, Muir AJ, Pound $\mathrm{D}$, Fried MW; ION-3 Investigators. Ledipasvir and sofosbuvir for 8 or 12 weeks for chronic HCV without cirrhosis. N Engl J Med 2014; 370: 18791888.

22. Lauer GM, Walker BD. Hepatitis $\mathrm{C}$ virus infection. N Engl J Med 2001; 345: 41-52.

23. Vince A, Židovec Lepej S, Bingulac-Popović J, Miletić M, Kuret S, Sardelić S, Vrakela IB, Kurelac I. Distribution of hepatitis C virus genotypes and subtypes in Croatia: 2008-2015. Cent Eur J Public Health 2018; 26: 159-163.

24. Vilibic-Cavlek T, Kucinar J, Kaic B, Vilibic M, Pandak N, Barbic L, Stevanovic V, Vranes J. Epidemiology of hepatitis $C$ in Croatia in the European context. World J Gastroenterol 2015; 21: $9476-9493$.

25. Madaliński K, Zakrzewska K, Kołakowska A, Godzik P. Epidemiology of $\mathrm{HCV}$ infection in Central and Eastern Europe. Przegl Epidemiol 2015; 69: 459-464.
26. Bouchardeau F, Cantaloube JF, Chevaliez S, Portal C, Razer A, Lefrère JJ, Pawlotsky JM, De Micco P, Laperche S. Improvement of hepatitis $\mathrm{C}$ virus $(\mathrm{HCV})$ genotype determination with the new version of the INNO-LiPA HCV assay. J Clin Microbiol.. 2007; 45: 1140-1145.

27. Chevaliez S, Bouvier-Alias M, Vandervenet C, Pawlotsky JM. HCV genotype determination in clinical practice: weaknesses of assays based on the 5'noncoding region and improvement with the core-coding region. Hepatology 2007; 46(Suppl 1): 839A.

28. Stelzl E, van der Meer C, Gouw R, Beld M, Grahovac M, Marth E, Kessler HH. Determination of the hepatitis $C$ virus subtype: comparison of sequencing and reverse hybridization assays. Clin Chem Lab Med 2007; 45: 167-170.

29. Verbeeck J, Stanley MJ, Shieh J, Celis L, Huyck E, Wollants E, Morimoto J, Farrior A, Sablon E, Jankowski-Hennig M, Schaper C, Johnson P, Van Ranst M, Van Brussel M. Evaluation of Versant hepatitis $C$ virus genotype assay (LiPA) 2.o. J Clin Microbiol.. 2008; 46: 1901-1906.

30. Alter MJ. Epidemiology of hepatitis C virus infection. World J Gastroenterol 2007; 13: 24362441.

31. Kirby Institute. HIV, Viral Hepatitis and Sexually Transmissible Infections in Australia. Annual Surveillance Report 2012.

32. Razali K, Thein HH, Bell J, Cooper-Stanbury M, Dolan K, Dore G, George J, Kaldor J, Karvelas M, Li J, Maher L, McGregor S, Hellard M, Poeder F, Quaine J, Stewart K, Tyrrell H, Weltman M, Westcott O, Wodak A, Law M. Modelling the hepatitis $C$ virus epidemic in Australia. Drug Alcohol Depend 2007; 91: 228-235.

33. Sievert W, Altraif I, Razavi HA, Abdo A, Ahmed EA, Alomair A, Amarapurkar D, Chen CH, Dou X, El Khayat H, Elshazly M, Esmat G, Guan R, Han KH, Koike K, Largen A, McCaughan G, Mogawer S, Monis A, Nawaz A, Piratvisuth T, Sanai FM, Sharara AI, Sibbel S, Sood A, Suh DJ, Wallace C, Young K, Negro F. A systematic review of hepatitis $C$ virus epidemiology in Asia, Australia and Egypt. Liver Int. 2011; 31(Suppl 2): 61-8o.

34. Yoshizawa H. Hepatocellular carcinoma associated with hepatitis $\mathrm{C}$ virus infection in Japan: projection to other countries in the foreseeable future. Oncology 2002; 62(Suppl 1): 8-17.

35. Tanaka Y, Hanada K, Orito E, Akahane Y, Chayama K, Yoshizawa H, Sata M, Ohta N, Miyakawa Y, Gojobori T, Mizokami M. Molecular evolutionary analyses implicate injection treatment for schistosomiasis in the initial hepatitis C epidemics in Japan. J Hepatol 2005; 42: 47-53.

36. Guidelines for the care and treatment of persons diagnosed with chronic hepatitis $\mathrm{C}$ virus infection. Geneva: World Health Organization; 2018. 